Tyndale Bulletin 69.1 (2018) 43-62

\title{
A POSSIBLE SCRIPTURAL PRECEDENT FOR PAUL'S TEACHING ON DIVORCE (AND REMARRIAGE?) IN 1 CORINTHIANS 7:10-15
}

\author{
Brian Neil Peterson \\ (bpeterson@leeuniversity.edu)
}

\begin{abstract}
Summary
This paper argues that in the same way Jesus' and the Pharisees' positions on divorce were rooted in the Torah, so, too, Paul, a man steeped in the Hebrew Scriptures, may have been influenced by the Torah when formulating his own teaching on a believer's freedom to remarry when abandoned by an unbelieving spouse. Here it is argued that Paul may have drawn upon the marital life of Moses, who appears to have remarried a Cushite woman after being abandoned by his wife Zipporah due to his Abrahamic faith.
\end{abstract}

\section{Introduction}

When it comes to family relational issues within the body of believers, perhaps no other issue has created more angst for pastors and church leaders than the issue of divorce and remarriage. ${ }^{1}$ Scarcely is a single family within most churches unscathed by the heartache experienced by a divorce. With the passing of no-fault divorce in 1970 in California, the effects of this new civil policy quickly affected churches throughout America. Now, almost fifty years later, most denominations have attempted to formulate some form of ecclesial policy on how to minister to those who enter the church (or are already there) and find themselves in the unfortunate position of being in the class of 'divorcee'. Inevitably, clergypersons of all stripes have appealed to the

1 I want to thank Craig Keener for reading an earlier version of this paper and offering valuable insights on how to improve it. 
teaching of Jesus and Paul for guidance, and rightly so. However, like many other controversial issues related to church polity, two main positions have emerged, often pitting believer against believer, pastor against pastor, or even denomination against denomination. ${ }^{2}$

In one camp, many argue that Paul not only agreed with Jesus' instruction on divorce for those who had an unfaithful spouse, but that in 1 Corinthians 7:15 Paul moved beyond the instruction of Jesus when he opened the door for the possibility of remarriage for those who have been abandoned due to their Christian faith. ${ }^{3}$ Paul's declaration that a

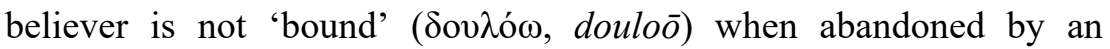
unbelieving spouse has offered comfort for the victims of abandonment in the possibility of remarriage. ${ }^{4}$ Yet those who adopt this understanding of 1 Corinthians 7:15 often face resistance from those in the second camp who insist that Jesus' instruction is clear in Matthew 5:32, Mark 10:11-12, 19:9, and Luke 16:18: the one who remarries, or marries someone who is divorced, except for immorality, commits adultery. ${ }^{5}$ Thus, according to the second camp, the option of

2 While there are many nuanced arguments associated with this topic, I have chosen to speak in broad terms when identifying the two main positions. For more nuanced positions, see for example, Gordon Wenham, William Heth, and Craig Keener, Remarriage after Divorce in Today's Church: 3 Views (Grand Rapids: Zondervan, 2006).

3 See, for example, the position of Roy E. Gane, Old Testament Law for Christians: Original Context and Enduring Application (Grand Rapids: Baker, 2017): 301; Craig Keener and Médine Moussounga Keener, Impossible Love (Minneapolis, MN: Chosen, 2016): 57; Craig Keener, 1 and 2 Corinthians (Cambridge: Cambridge University Press, 2005): 65; Leon Morris, 1 Corinthians (TNTC 7; Grand Rapids: Eerdmans, 1999): 107; Hans Conzelmann, 1 Corinthians, trans. James W. Leitch (Hermeneia; Philadelphia: Fortress, 1975): 123; F. F. Bruce, I \& II Corinthians (NCBC; Grand Rapids: Eerdmans, 1971): 70; Craig Blomberg, 'Marriage, Divorce, Remarriage, and Celibacy: An Exegesis of Matthew 19:3-12', TrinJ 11.2 (1990): 161-96; William Orr and James Arthur Walther, 1 Corinthians (AB 32; New York: Doubleday, 1976): 214; Preben Vang, 1 Corinthians (Grand Rapids: Baker, 2014): 104.

4 Keener, 1 and 2 Corinthians, 65, cites ancient divorce contracts that allowed for remarriage (cf. m. Gitin 9:3; Chrysostom, Corpus Papyrorum Iudaicarum, 2:10-12, $\S 144 ;$ P. Grenf., 2.76.10-11). See also D. Instone-Brewer, Divorce and Remarriage in the Bible: The Social and Literary Context (Grand Rapids: Eerdmans, 2002): 288-89.

5 E.g., A. Robertson and A. Plummer, A Critical and Exegetical Commentary on the First Epistle of St Paul To the Corinthians (ICC; 2nd edn; Edinburgh: T\&T Clark, 1914): 143; William A. Heth, 'Divorce and Remarriage: The Search for an Evangelical Hermeneutic', TrinJ 16.1 (1995): 63-100 at 84 (note especially 66 n.13); or William A. Heth and Gordon J. Wenham, Jesus and Divorce: The Problem with the Evangelical Consensus (Nashville: Thomas Nelson, 1985): 140-44. However, see Blomberg's concise rebuttal of Heth and Wenham in 'Marriage', 188. Since his co-authored work in 1985, Heth has changed his mind and now allows for remarriage in cases of adultery and abandonment (see Remarriage after Divorce in Today's Church, 43). 
remarriage, if at all, ${ }^{6}$ is only for those who have been on the receiving end of the actions of an unfaithful spouse. ${ }^{7}$

In light of this contentious issue, in this paper, I will attempt to offer some insight into the possible Sitz im Text that may have informed Paul's instruction on divorce and remarriage in 1 Corinthians 7:10-15. I will argue that in the same way Jesus and the Pharisees appealed to Moses and the Torah for their positions on divorce, so, too, Paul may very well have appealed to the life of Moses and Torah for his instruction on the possibility of remarriage, which many suggest he intimates in 1 Corinthians 7:12-15. Indeed, Paul may very well have had in mind Moses' own apparent marital struggles with his wife Zipporah as described in Exodus 4:24-26, 18:2, and Numbers 12:1 when offering insight into the plight of the abandoned believer. I will conclude that it is possible that the enigmatic language of 1 Corinthians 7:12-15 was Paul's way of appealing to his inspired interpretation of these three cryptic portions of Scripture when offering instruction on divorce and remarriage to the church at Corinth, and, by extension, for all believers.

\section{Jesus' Instruction on Divorce}

Jesus' instruction on divorce stems from his interaction with the Pharisees (Matt. 19:3-9; Mark 10:2-12; 19:9) and his teaching during the Sermon on the Mount (Matt. 5:32; cf. Luke 16:18). In the former case, both the Pharisees and Jesus appeal to the Torah as the basis for their positions. The Pharisees focus on Moses' instruction on divorce as found in Deuteronomy $24: 1-3^{8}$ and Jesus appeals to the creation narratives in Genesis $(1: 27 ; 2: 24) .{ }^{9}$ Of interest is the fact that both

6 E.g. Gordon Wenham, Remarriage after Divorce in Today's Church, 19-42, rejects remarriage even for those who are the innocent party in a divorce due to adultery. Similar positions are common: see Instone-Brewer, Divorce and Remarriage, 238-67.

7 When addressing 1 Cor. 7:15 Gordon Fee, The First Epistle to the Corinthians (NICNT; Grand Rapids: Eerdmans, 1993): 302-03, 306 takes the middle ground and argues that although Paul may have allowed remarriage in some instances (e.g. for fornication) remarriage is not in view in this text. Others, like F. W. Grosheide, The First Epistle to the Corinthians (NICNT; Grand Rapids: Eerdmans, 1983): 166, do not broach the subject at all.

8 For more on the two opposing rabbinic positions, see Blomberg, 'Marriage', 16365.

9 On the rights of women to divorce in ancient Israel/Judaism, see Bernadette J. Brooten, 'Konnten Frauen im alten Judentum die Scheidung betreiben?' Evangelische 
appeal to the instruction of Moses as found in the Torah. Of course, Jesus counters the Pharisees' argument by pointing to the spirit of the Law (cf. Matt. 5:31-32): it was due to the hardness of people's hearts that Moses allowed divorce, something that was never part of God's plan for marriage (Matt. 19:8; Mark 10:5). In fact, Jesus argues his position based upon the instruction given directly from God himself in Genesis 1 and 2. In these texts of Genesis, God established the genders of male and female (1:27) followed by the institution of marriage (2:24); the covenantal bond within which male and female come together for the purpose of partaking in the divine mandate to create new life (i.e. children). ${ }^{10}$

\section{Paul's Instruction on Divorce and Remarriage}

\subsection{Divorce}

In 1 Corinthians 7:10-11, Paul gives instruction on the issue of believers divorcing/separating by appealing directly to Jesus' position on the topic. Here, Paul insists that if believing spouses separate they

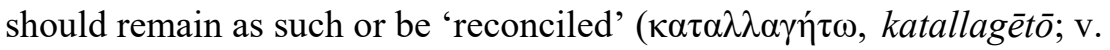
11). ${ }^{11}$ At verse 12 , Paul moves to another marital scenario which may end in divorce, namely, a marriage between a Christian and a pagan. Based upon his discussion in 7:12-16 (cf. 2 Cor. 6:15) it is possible that this is dealing with those who have become believers, but their spouses refuse to follow suit, or have not yet done so (v. 16). On this topic, Paul makes it clear that he is speaking from his own wisdom (v. 12); ${ }^{12}$

Theologie 42.1 (1982): 65-80; Eduard Schweizer, 'Scheidungsrecht der jüdischen Frau?' Evangelische Theologie 42.3 (1982): 294-300; and Bernadette J. Brooten, 'Zur Debatte über das Scheidungsrecht der jüdischen Frau', Evangelische Theologie 43.5 (1983): 466-78 (as noted by Blomberg, 'Marriage', 165 n.16).

10 See Brian Neil Peterson, 'Does Genesis 2 Support Same-sex Marriage?: An Evangelical Response', JETS 60.4 (2017): 681-96.

11 See discussion by John Murray, 'Divorce: Part 4', WTJ 10.2 (1948): 168-91 at 16875. Some have suggested that based upon his use of meneto agamos ( $\mu \varepsilon v \varepsilon \dot{\tau} \tau \omega$ ö $\gamma \alpha \mu \circ$, 'remain unmarried') in verse 11 Paul may be referring to the Roman law of divorce-byseparation and as such may be acknowledging that they are already divorced. In this case, Paul would be telling them not to remarry. I would like to thank the reviewer for bringing this to my attention.

12 J. D. G. Dunn, The Theology of Paul the Apostle (Grand Rapids: Eerdmans, 1998): 189 n. 30 notes that every time Paul moves beyond the instructions of Jesus it has to do with some controversial issue (cf. 1 Cor. 7:12-15; 9:15-18; 11:17-22). 
however, the reader is assured he does have the mind of Christ and insight from the Spirit (cf. 7:25, 40; cf. 1 Cor. 14:37). ${ }^{13}$ In these cases, Paul instructs the believer to remain with his/her spouse if the unsaved person is willing to dwell with him/her (v. 13). In situations where an unbelieving spouse refuses to do so - something Jesus would not have encountered prior to the establishment of the New Covenant ${ }^{14}$ (John 20:19-23) - then the believer is free to allow the unbelieving spouse to depart from the marriage (7:12-15). In fact, it appears that 'bitter strife' may have been the norm in some of these situations due to a believer's new status in Christ. ${ }^{15}$ It is at this juncture in Paul's teaching that one is confronted with the question of whether Paul in fact is teaching the Corinthians that if an unbelieving spouse leaves a marriage then the believer is free to remarry.

\subsection{Remarriage}

The cryptic phrase often cited by modern interpreters for the support of remarriage appears in 1 Corinthians 7:15. The text reads 'But if the unbelieving spouse departs, let them depart; the Christian brother or

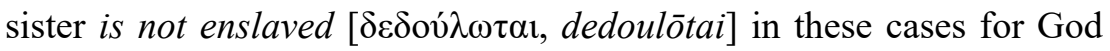
has called us to peace' (italics added for emphasis; author's translation). The key word here is the term for 'bondage'/'bound'

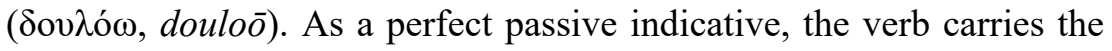
nuance that what is a completed event in the past with effects into the future (perhaps one's marriage contract) is no longer binding on the believer. Again, the issue is whether someone in this state can be remarried. ${ }^{16}$ Now while this particular interpretive issue has been debated ad nauseam vis-à-vis Paul's later use of the verb deō ( $\delta \dot{\varepsilon} \omega$, 'bound') and the adjective eleutheros (غ̇ $\bar{\varepsilon} \varepsilon \dot{\theta} \theta \varepsilon \rho \varsigma$, 'free') in 7:39 (cf. Rom. 7:2-3 $)^{17}$ perhaps some clarity can be gained about Paul's teaching

13 So, too, Morris, 1 Corinthians, 106; Blomberg, 'Marriage', 186-87; C. K. Barrett, The First Epistle to the Corinthians (Black's NT Commentary 7; Peabody, Massachusetts: Hendrickson, 1968): 163-64; Keener, 1 and 2 Corinthians, 64; and Murray, 'Divorce', 176.

14 Dunn, The Theology of Paul, 696-97; Fee, First Corinthians, 298; Richard B. Hays, First Corinthians (Interpretation; Louisville, Kentucky: John Knox, 1997): 120-21.

15 Dunn, The Theology of Paul, 697.

16 See Raymond F. Collins, First Corinthians (Sacra Pagina; Collegeville, Minnesota: The Liturgical Press, 1999): 272.

17 For example, see Heth, 'Divorce and Remarriage', 85-90; Murray, 'Divorce', 18191; Craig Blomberg, 1 Corinthians (The NIV Application Commentary; Grand Rapids: Zondervan, 1994): 140. 
based upon his primary source for instruction. In this vein, apart from his reliance on the words of Jesus, Paul consistently appeals to the Hebrew Scriptures to bolster his positions. This is further supported by

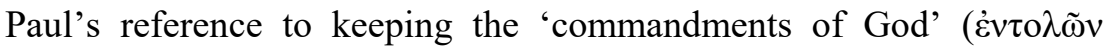
$\theta \varepsilon o \tilde{v}$, entolōn theou) in verse 19. Interestingly, entole ('̌vio $\lambda \eta$, 'commandment') is the term normally used by Paul to refer to the Hebrew Law (Rom. 7:8-13; 13:9; Eph. 2:15; 6:2; 1 Tim. 6:14; cf. 1 Cor. 14:37), as is also common in the LXX. Only in two cases in the Pauline corpus does entole refer to Paul's or someone else's command (Col. 4:10; Titus 1:14). As such, it seems likely that when Paul was looking for a precedent for giving instruction on the abandonment of a believer by a non-believer that he would have turned to the Hebrew Law.

\section{Paul's Appeal to the Torah for a Precedent on Remarriage}

It goes without saying that Paul appealed to the Mosaic Law for informing his teaching of Christians throughout the Roman Empire. ${ }^{18}$ As such, it should not be that surprising that Paul would appeal to his training in the Law and Hebrew Scriptures to address the new situation of believers who were abandoned by their unbelieving spouses (cf. also 1 Tim. 5:8). The problem is, however, that such a situation is rarely addressed in the Hebrew text. At best, perhaps three explicit cases could be proposed. Firstly, Paul may have adapted Ezra and Nehemiah's instruction on divorce (Ezra 9-10; Neh. 13:23-30), found in the Writings section of the Hebrew Bible. However, this situation does not deal with abandonment, but rather Israel's direct violation of the Law not to marry those from Canaan and its environs (cf. Gen. 24:3, 37; Exod. 34:16; Deut. 7:3; Josh. 23:12; Judg. 3:6). Secondly, in the book of Judges - found within the Former Prophets - an unnamed Levite's concubine 'plays the harlot' and abandons him. ${ }^{19}$ Although the

18 E.g. E. P. Sanders, Paul and Palestinian Judaism (Minneapolis: Fortress, 1977); Dunn, The Theology of Paul the Apostle (1998); Frank Thielman, Paul and the Law: A Contextual Approach (Downers Grove, Illinois: InterVarsity, 1994); Scott J. Hafemann, Paul, Moses, and the History of Israel (Peabody, Massachusetts: Hendrickson, 1995).

19 Even here some suggest that the verb zanah (זָנזָה) can be translated as 'she played the harlot' or as 'she got angry'. See Daniel Block, Judges, Ruth (NAC 6; Nashville: Broadman \& Holman, 1999): 523. 
Levite re-established the union (Judg. 19:1-10), this is not a fitting parallel either, due to the fact that the account deals with abandonment as well as unfaithfulness. Thirdly, in a metaphorical sense, the Latter Prophets often used the language of 'marriage' and 'divorce' when speaking of Israel's relationship with YHWH (Jer. 3; Ezek. 16; 23; Hos. 1-3). A prime example of this is found in the book of Hosea. ${ }^{20}$ At first glance Hosea's marriage to Gomer could offer some semblance of what a believer goes through when abandoned by an unbeliever. Unfortunately, here again the story fails to match what Paul seems to be teaching. Not only does Gomer abandon Hosea; she also is unfaithful to her husband. What is more, after Hosea buys Gomer back (Hos. 3:1-2), Gomer does not appear to have had full marital and conjugal rights as formerly (Hos. 3:3-5). ${ }^{21}$

That leaves just the Torah for a possible Sitz im Text fitting Paul's instruction on abandonment in 1 Corinthians 7:12-15. Much like the Pharisees' and Jesus' use of the Torah in their discussions on marriage (see above), Paul appears to have appealed to the Torah as well, only instead of looking at the legislation of Genesis or Deuteronomy Paul appealed to the narratives of Exodus and Numbers. Three narratives dealing with Moses himself may shed light on Paul's teaching: Exodus 4:24-26, 18:2, and Numbers 12:1.

\subsection{Evidence from Exodus 4:24-26}

When Moses fled from Egypt after killing an Egyptian man, he ended up in the land of Midian (Exod. 2:16). There, he quickly gained favour with Jethro, who is described as the 'priest of Midian.' 22 After a period of time, Jethro gave his daughter, Zipporah, to Moses as a wife (Exod. 2:21). Sometime later, Zipporah bore Moses two sons: Gershom and Eliezer. It is important to note that this marriage is never sanctioned by God. In fact, some have posited that it is possible that Zipporah was a Baal worshipper (cf. Num. 25:1-16, 31:1-20), and her father, Jethro, the

\footnotetext{
20 See comments by Heth, 'Divorce and Remarriage', 81. Heth brings up Hosea's example in his discussion on Jesus' teaching on divorce in Matthew.

21 E.g. Thomas McCominsky, 'Hosea', in vol. 1 of The Minor Prophets: An Exegetical and Expository Commentary, ed. Thomas Edward McCominsky (3 vols; Grand Rapids: Baker, 1992): 53.

22 For a similar scenario from the ancient Near East, see the Egyptian Tale of Sinuhe (ANET, 18-22).
} 
priest of Baal. ${ }^{23}$ Of course, this position creates problems because later Jethro offered sacrifices to YHWH (Exod. 18:12), although 18:11 suggests he may have had a 'conversion' experience. At this time it appears that spiritually Moses was at a low point in his life and not committed to the God of his fathers. ${ }^{24}$ Indeed, one could say that Moses' life, in some ways, was very similar to that of an unbeliever in Paul's day. This is important to the following discussion due to the fact that Moses' 'conversion' and embracing of the Abrahamic religion after the burning bush experience (Exod. 3:6, 15-16; 4:5) appears to have caused marital problems.

The burning bush event capped Moses' forty-year stay in Midian. At this juncture, YHWH called Moses to return to Egypt (Exod. 3:114). During the journey back to Egypt, with his wife and two children at his side, ${ }^{25}$ the reader is confronted with an enigmatic account of how YHWH sought to kill Moses along the way. ${ }^{26}$ It is only the quick actions of Zipporah (because Moses was incapacitated ${ }^{27}$ ) that saved Moses' life. ${ }^{28}$ The question that has plagued commentators is who

23 J. Daniel Hays, 'Moses: The Private Man Behind the Public Figure', Bible Review 16.4 (2000): 16-26, 60-63 at 18; Hays, 'A Biblical Perspective on Interracial Marriage', Criswell Theological Review 6.2 (2009): 5-23 at 12-13. Cornelis Houtman, Exodus, trans. Johan Rebel and Sierd Woudstra (vol. 1; vol. 2; Leuven: Peeters, 1993): vol. 1, 441 notes that according to Ephraem of Syria (fourth century AD) Zipporah wanted to remain faithful to her religion and opposed circumcision. However, Hans Kosmala, "The "Bloody Husband", VT 12.1 (1962): 14-28 at 20-21, suggests that Jethro was a worshipper of a god very similar to YHWH.

24 So, too, Hays, 'Biblical Perspective', 13; Hays, 'Moses', 18.

25 Historical critical analyses of this text have been legion and full of fanciful emendations and assertions (see, for example, the perspective of Kosmala, 'The "Bloody Husband", 14-28). The fact remains that the canonical text is the one we must assess not some theoretical recreation.

26 For a bibliography of the numerous interpretations of this passage, see Duane Garrett, A Commentary on Exodus (Grand Rapids: Kregel, 2014): 225 n.108. See also the overview by William Johnstone, Exodus 1-19 (Smyth \& Helwys Bible Commentary; Macon, Georgia: Smyth \& Helwys, 2014): 116-17; John Durham, Exodus (WBC 3; Waco, Texas: Word Books 1987): 56-59; Kosmala, 'The "Bloody Husband"', 14-28; and Brevard Childs, The Book of Exodus (OTL; Philadelphia: Westminster, 1974): 95-101.

27 Houtman, Exodus, vol. 1, 437.

28 Source critics struggle with who is in view here - Moses or his son. See William H. C. Propp, Exodus 1-18 (AB 2; New York: Doubleday, 1999): 195-96, 233-34. Despite the debate, many see the attack as against Moses. See for example, William H. Propp, 'That Bloody Bridegroom (Exodus IV 24-26)', VT 43.4 (1993): 495-518 at 499, 514; Robert Alter, Five Books of Moses: A Translation with Commentary (New York: W.W. Norton \& Company, 2004): 331; Houtman, Exodus, vol. 1, 435; Walter Kaiser Jr, Exodus (EBC; Grand Rapids: Zondervan, 1990): 332; Bruce Wells, 'Exodus', in Zondervan Illustrated Bible Backgrounds Commentary, ed. John H. Walton (Grand 
Zipporah actually circumcised. Was it Moses, Gershom, or Eliezer?29 Most scholars agree that contextually it appears that Moses had not circumcised one of his sons. ${ }^{30}$ Although all the interpretive issues of the text cannot be handled here, it is important to note that this cryptic pericope may have been included in Exodus for the very reason of showing why Moses ended up without Zipporah by his side in Egypt (Exod. 18:2) and why he felt free to remarry later in Numbers 12:1. What is more, it is indeed possible that within this cryptic account the reader finds not only a possible clue to Moses' changed marital status, but also Paul's possible precedent for allowing the abandoned believer to remarry.

By the end of this short and somewhat out-of-place pericope, it looks like Moses and Zipporah part ways. ${ }^{31}$ In fact, it appears that Zipporah was the one who left Moses due to his commitment to the Abrahamic tradition/faith and its requirements. The sign of the Abrahamic covenant was circumcision (Gen. 17). ${ }^{32}$ Both in Genesis (17:14), and later in Exodus (12:48), the texts state that a male could

Rapids: Zondervan, 2009): 177; B. Embry, 'The Endangerment of Moses: Towards a New Reading of Exodus 4:24-26', VT 60.2 (2010): 177-96; and Johnstone, Exodus 1$19,114$.

29 Many scholars suggest the son is Gershom., e.g. Embry, 'The Endangerment of Moses', 177, 186, 190 n.44, 193; G. W. Ashby, 'The Bloody Bridegroom: The Interpretation of Exodus 4:24-26', ExpTim 106.7 (1995): 203-5 at 204; Propp, Exodus 1-18, 236; Walter Beltz, 'Religionsgeschichtliche Marginalie zu Ex 4:24-26', ZAW 87.3 (1975): 209-11 at 209; Moshe Greenberg, Understanding Exodus (New York: Behrman House, 1969): 113; and Nahum Sarna, Exodus (JPS Torah Commentary; New York: The Jewish Publication Society, 1991): 25. Targum Pseudo-Jonathan notes that an 'agreement' had been made between Jethro and Moses to circumcise the younger son, Eliezer, but not Gershom. This is clearly an attempt to harmonise the text. Sarna asserts that the child is Gershom based upon the focus of the firstborn in the immediate context of 4:22-23 (he also notes Babylonian Talmud Nedarim 31b-32a; Jerusalem Talmud Nedarim 3:16/38b; Exodus Rabbah 5:8; Targum Jonathan and Shadal). The problem is that no reference to the person's identification is given (note esp. b. Ned. 31b). It seems more likely that it is the younger son, Eliezer, a position adopted by some rabbinic interpreters (Samuel ben Hofni, Saadyi, and Ramban; as noted by Sarna, 242 n.35). See also Vermes, 'Baptism and Jewish Exegesis', 316-17. For an overview of the rabbinic literature on this verse, see Greenberg, Understanding Exodus, 110-14.

30 See also comments by Beltz, 'Religionsgeschichtliche', 209.

31 Following the hero genre, Alter, Five Books of Moses, 331, suggests that this narrative served as a 'rite of passage' before Moses embarked on his mission. See also Gideon Miller, 'The "Bloody Bridegroom" in Light of the Joseph Narrative', JBQ 41.2 (2013): $113-18$ at 116-17.

32 Most interpreters point out that the major problem here was the failure of Zipporah and Moses to circumcise their son. See Géza Vermes, 'Baptism and Jewish Exegesis New Light from Ancient Sources’, NTS 4.4 (1957-1958): 308-19 esp. 309-13. 
not be a part of the nation of Israel without being circumcised. Apparently, Zipporah (or her father, Jethro) had rejected this practice, ${ }^{33}$ a conclusion adopted by Targum Jonathan, the Fragmentary Targum, and Targum Neofiti. ${ }^{34}$

Adding to the mysterious nature of the account is that fact that the text tells us Moses took both sons with him when he returned to Egypt (4:20), yet Zipporah circumcised only one son when YHWH attacked/restrained Moses (4:25). It seems very likely that Gershom, the oldest, had been circumcised, but the event and hearing her baby's screams during the rite must have been so traumatic for Zipporah that she refused to circumcise her second son. ${ }^{35}$ Although some argue that circumcision was practised by the Midianites, at best this appears to have been only a puberty rite. ${ }^{36}$ As such, circumcising a baby may have been too troubling for Zipporah to do it again. It is very likely that this became a point of contention between Moses and his wife. ${ }^{37}$ This would explain why Zipporah knew exactly what to do to stay the hand of YHWH against Moses. ${ }^{38}$ What is more, the tension between Moses and Zipporah is palpable when she throws ${ }^{39}$ her son's foreskin at Moses' feet ${ }^{40}$ and exclaims 'A bridegroom ${ }^{41}$ of blood you are to me!' $(4: 25) \cdot{ }^{42}$

33 C. F. Keil, Exodus (COT 1; Peabody, Massachusetts: Hendrickson, 2001): 299.

34 So Sarna, Exodus, 25; Embry, 'The Endangerment of Moses', 181; Cornelis Houtman, 'Exodus 4:24-26 and Its Interpretation', JNSL 11 (1983): 81-105 at 87-88; and Vermes, 'Baptism and Jewish Exegesis', 311-13.

35 So, too, Ronald B. Allen, 'The "Bloody Bridegroom" in Exodus 4:24-26', BSac 153 (1996): 259-69 at 267-68. See also comments by Keil, Exodus, 298 and Garrett, Exodus, 225. Note also that the LXX renders the phrase in a completely different manner: 'The blood of my son's circumcision is stopped.' Scholars question this reading. It may represent a different Vorlage/text tradition perhaps reflective of the Targums (Houtman, Exodus, vol. 1, 442). A number of other versions follow the MT: Aquila, Symmachus, Theodotion, Peshita, Vulgate. See Houtman, Exodus, vol. 1, 442 and Kosmala, 'The "Bloody Husband"', 25-28.

36 Allen, “"Bloody Bridegroom”, 267-68.

37 So, too, Kaiser, Exodus 333 and Houtman, Exodus, vol. 1, 441.

38 Some suggest that Moses told her what was wrong. See discussion by Garrett, Exodus, 226.

39 The verb can mean to touch (see NIV, NRS, RSV, TNK). Here I am following the more intense action of casting or throwing, which is used by the translators of the NASB, KJV, NKJV, and the NLT. See also Houtman, 'Exodus 4:24-26', 85; Hays, 'Moses', 25 and Keil, Exodus, 299. Contra Kosmala, 'The "Bloody Husband"', 23, the translation of the verb naga' as 'to cast' is also found in (Isa. 25:12; 26:5; Ezek. 13:14; Lam. 2:2).

40 While 'feet' can be understood as a euphemism for male genitals, here it seems most likely that Zipporah literally throws her son's foreskin at Moses' feet. Beltz, 
Scholars have spilt much ink over who Zipporah is addressing as a

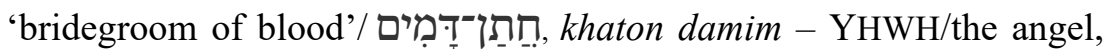
her son, or Moses? ${ }^{43}$ Even though scholars rightly note that khaton damim is usually used by in-laws to speak of a groom, a son-in-law, or other close family male relation, ${ }^{44}$ this may very well be the reason Zipporah is using it. She is so upset with Moses, even though he is her husband, that she uses the phrase to in a sense distance herself from him (or perhaps Moses' $\operatorname{God}^{45}$ ). It is clear that Zipporah does not appear to be happy with the situation. ${ }^{46}$ Interestingly, Zipporah's last recorded words in the Bible are in fact these same words followed by the phrase 'because of the circumcisions' (לַפמוֹלתת, lammulot; v. 26). ${ }^{47}$ Note that Zipporah uses the plural of circumcision (i.e. mulot) perhaps to highlight the circumcision now of both her sons: Gershom formerly, and now Eliezer. ${ }^{48}$ After this event Zipporah apparently left Moses and returned to her father in Midian. ${ }^{49}$ If this is the case, then one could make the argument that Zipporah abandoned Moses due to his Abrahamic faith, thus behaving in an equivalent manner to the unbeliever who abandons a Christian, as noted by Paul in 1 Corinthians

'Religionsgeschichtliche', 110, erroneously propounds that Zipporah touched the foreskin to the pudenda of a cult statue representing YHWH. By this act YHWH adopted the son of Moses and Zipporah metaphorically became the wife of YHWH.

41 The term khatan can mean 'son-in-law' but here 'bridegroom' seems most appropriate as noted by most English translations. Scholars have spilt much ink over who Zipporah is speaking to (YHWH, her son, or Moses). For an alternate interpretation/cognate of khatan in Arabic and Akkadian meaning 'to circumcise' or 'to protect', see Sarna, Exodus, 26.

42 See Houtman, Exodus, vol. 1, 442-43 and the scholars he lists who hold this position. For an alternate interpretation, see Garrett, Exodus, 226-32. Garrett's explanation of Exod. 18:2 (see p. 442) is not convincing in light of the apparent conflict of 4:24-26.

43 Houtman, 'Exodus 4:24-26', 85, 90.

44 See Hays, 'Moses', 20-21, 25, for a discussion on the possible fluidity of khatan in the ancient Near East.

45 Allen, "'Bloody Bridegroom", 268-69, may be correct that Zipporah spoke these words to the incarnate deity when she cast the foreskin at the deity's feet who was restraining Moses. Either way, Zipporah is not happy with the religion of Moses, which requires infant circumcision.

46 Allen, "'Bloody Bridegroom"”, 267.

47 See also Serge Frolov, 'The Hero as Bloody Bridegroom: On the Meaning and Origin of Exodus 4,26', Biblica 77.4 (1996): 520-23 at 521.

48 See comments by Houtman, Exodus, vol. 1, 438, 442 and Keil, Exodus, 298-99.

49 So, too, Hays, 'Moses', 26 and Allen, “"Bloody Bridegroom”', 269. See comments by Garrett, Exodus, 226, 442. While Garrett (442) downplays the idea of divorce in Exod. 18:2, he nonetheless posits that if there was a divorce Zipporah may very well have initiated it. 
7:15. Moreover, the contentious atmosphere of the event in $4: 25$ in ways mirrors Paul's instruction to the Corinthians that God has called

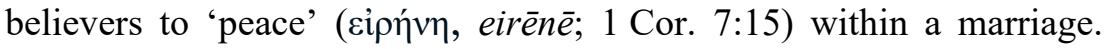
Marriages that generate contentious arguments due to a 'believer's' faith, as seen here with Moses and Zipporah over circumcision, are not God pleasing. In these situations, if the unbeliever does not want to remain in the marriage, the believer should let him or her depart, as Moses seemed to have done with Zipporah.

\subsection{Evidence from Exodus 18:2}

Now, while some may protest that the scenario described above is mere speculation, it is not so farfetched when one reads on within the account of Exodus. After Moses completes his task of rescuing Israel from Egypt - apparently alone, without his wife and children - the reader is informed that upon arriving at Sinai Jethro brought Zipporah and her two sons to see Moses. Here the reader is alerted to the fact that Moses had 'sent' (שָָָׁ, shalakh) Zipporah back to her father, no doubt due to the earlier altercation in Exodus 4:24-26.50

If one follows only the Hebrew text it is certainly possible that Zipporah wanted to stay with Moses after the circumcision fiasco. The important part of the Hebrew text of 18:2 says that Jethro brought

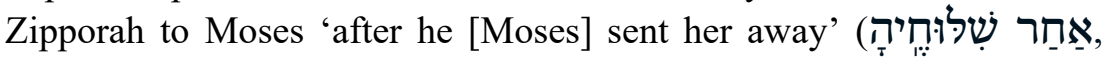
'akhar shillukheha $\left.{ }^{51}\right) .{ }^{52}$ Based upon this phrase, some may argue that

50 Contra Kaiser, Exodus, 411, and Alter, Five Books of Moses, 416-17, who argue for an amicable reunion. Some base this conclusion on the fact that according to the Mekhilta a third-century AD rabbinic commentary on Exodus and Midrash HaGadol (seventh century), Aaron was the one who encouraged Moses to send his wife and children back to Midian due to the hardships they would encounter in Egypt. See more on this in Naomi Koltun-Fromm, 'Zipporah's Complaint: Moses is not Conscientious in the Deed! Exegetical Traditions of Moses' Celibacy' in The Ways that Never Parted, ed. Adam H. Becker and Annette Yoshiko Reed (Texts and Studies in Ancient Judaism 95; Tübingen: Mohr Siebeck, 2003): 283-306 at 289; Alter, Five Books of Moses, 416.

51 Contra Propp, Exodus 1-18, 629, who follows the work of the rabbinic interpreters Ibn Ezra, Bekhor Shor, and Rashbam, and suggests that shalakh has to do with a 'wedding gift'. Note also the similar position by Gregorio Del Olmo Lete, 'ahar šillûhèhā' (Ex 18,2)', Biblica 51.3 (1970): 414-16. In the context, this does not seem to work very well as an interpretation. Indeed, most English translations do not follow this understanding (cf. NASB, ESV, KJV, NIV, NJB, NLT NRV), nor does the Jewish TNK.

52 Johnstone's suggestion that this phrase is a 'lame explanatory addition' due to source and redaction efforts is not at all satisfying (Exodus 1-19, 374). His redactional reconstruction is highly speculative. 
Moses may have been the instigator of the separation or of a divorce, ${ }^{53}$ if one actually occurred (cf. Josephus Ant. 3:63), for indeed shalakh can be used to speak of divorce (e.g. Deut. 22:19, 29; 24:1, 3; Isa. 50:1; Jer. 3:1; Mal. 2:16), ${ }^{54}$ a fact further supported by the similar usage of shalakh in post-biblical Hebrew. ${ }^{55}$ Yet it is also true that in many cases

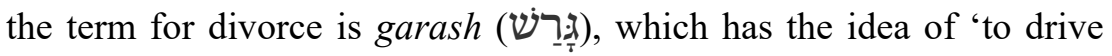
out' (Lev. 21:7; 21:14; 22:13; Num. 30:9; Ezra 10:3, 19; Ezek. 44:22). One is still left wondering what actually happened between Moses and Zipporah: did they divorce, or did Zipporah abandon Moses?

Support for the position that Zipporah abandoned Moses can be found in the LXX rendering of Exodus 18:2. According to the LXX, something Paul used often, there are three different terms used for

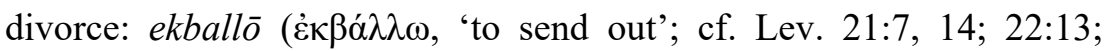

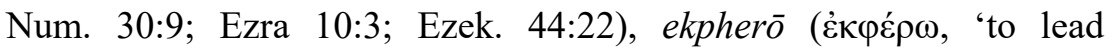
out/away'; cf. Ezra 10:19), and exapostellō ( $\dot{\varepsilon} \xi \alpha \pi$ o $\tau \tau \dot{\varepsilon} \lambda \lambda \omega$, 'to send forth'/'away'; cf. Deut. 22:19, 29; 24:1, 3; Isa. 50:1; Jer. 3:8). None of these terms are used in Exodus 18:2 of the LXX. In 18:2 the author of the LXX renders the Hebrew phrase 'akhar shillukheha ('after he sent

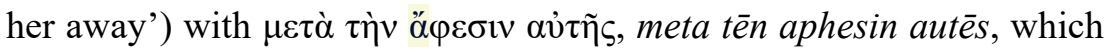
literally translates 'after her [Zipporah's] release'. Every other time (twenty-eight in total) that the LXX uses the word aphesis in the Torah it has the idea of releasing someone or something from an obligation or debt often related to the Sabbatical or Jubilee years (e.g. Exod. 23:11; Lev. 16:26; 25:10; 27:18; Deut. 15:1, 3). ${ }^{56}$

It is noteworthy that Paul uses the verbal form of this same word

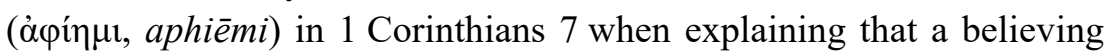
spouse should not 'send away'/'release' an unbelieving spouse from the marriage bond if he or she desire to stay married to the believer (1 Cor. 7:11-13). Therefore, similar to the usage of aphiemi in the Torah, Paul's use of the verb has a legal nuance of being released 'from a legal

53 Some Jewish interpreters interpreted this text this way. See also Propp, Exodus 118, 629; Johnstone, Exodus 1-19, 389 n. 4; Houtman, Exodus, vol. 2, 404; and KoltunFromm, 'Zipporah's Complaint', 290, 302-05.

54 See this conclusion in the Mekhilta (as noted by Childs, Exodus, 320).

55 See Garrett, Exodus, 439 n.60.

56 Exod. 23:11 (land is released from being worked); Lev. 16:26 (the release of the goat on the Day of Atonement); 25:10 (Jubilee Year release of debts); 27:18 (release of a field after a vow is fulfilled); and Deut. 15:1, 3 (Sabbatical Year release of debts). Various inflected forms of the word appear in the Torah all of which fall into the category of something being released (cf. Lev. 25:10-13, 28, 30, 31, 33, 40, 41, 50, 52,54; 27:17, 18, 21, 23, 24; Num. 36:4; Deut. 15:2, 9; 31:10). 
or moral obligation'. ${ }^{57}$ In a patriarchal setting like that of Moses, the 'release' (shalakh) of Zipporah would have been undertaken by Moses, hence the phraseology in the Hebrew text of Exodus 18:2. Nevertheless, this does not of necessity mean that Moses initiated the separation. If Zipporah wanted to depart from the marriage arrangement after the Exodus 4 fiasco due to Moses' Abrahamic faith, Moses may very well have allowed her to leave, that is, he released her from her marital obligations. This would explain why Zipporah and her sons are never mentioned in the interirn while Moses is in Egypt. Furthermore, when Jethro visits Moses at Sinai, Zipporah is never mentioned as part of the events beyond the fact that she came with her father. After Moses spends a few days with his father-in-law and his children it appears that they all returned to Midian. Although the text only records that Jethro returned home (Exod. 18:27), this does not mean that Zipporah and her sons did not go with him. ${ }^{58}$

Of course, some might still protest and say that here in 18:2 the reunion is warm/cordial ${ }^{59}$ and Zipporah is called Moses' wife (מֶֶָׁת משֹשֶה , 'eshet Mosheh; Exod. 18:2) while Jethro is repeatedly called his 'father-in-law' (זָת , khoten; Exod. 18:1, 2, 5, 6, 7, 8, 12 (2x), 14, 15, 17, 24, 27). However, this does not mean that Moses and Zipporah were still together. ${ }^{60}$ Biblical Hebrew has no word for 'ex-wife'. ${ }^{61}$ For example, in 1 Samuel 27:3, 30:5, 2 Samuel 2:2, and 3:3 Abigail is

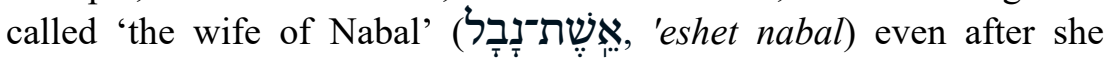
marries David. English translators muddy the interpretive waters by rendering the phrase 'eshet nabal as 'the widow of Nabal'. ${ }^{62}$ In light of these considerations, one could conclude that Moses was technically divorced or permanently separated (conjugally) from Zipporah. This seems to be the case in light of Numbers 12:1.

\subsection{Evidence from Numbers 12:1}

In Numbers 12, another cryptic account relates Aaron and Miriam's rebellion against Moses. Here the reader is told that Moses' siblings

\footnotetext{
$57 B D A G$ (2000): 156.

58 So, Allen, “'Bloody Bridegroom”, 269, and contra Hays, 'Biblical Perspective',

12-13; Hays, 'Moses', 26.

59 So Houtman, Exodus, vol. 2, 404.

60 Contra Sarna, Exodus, 98.

61 Garrett, Exodus, 442.

62 Garrett, Exodus, 443-44.
} 
rebelled against Moses due to his 'Cushite wife' (Num. 12:1). ${ }^{63}$ The major problem is the identification of this Cushite wife. ${ }^{64}$ Some have posited she is none other than Zipporah (so Ibnu-Ezra and Augustine). ${ }^{65}$ However, three factors push against this conclusion. ${ }^{66}$ First, why would Miriam and Aaron only now have an issue with Zipporah? If she had been travelling with Moses in the wilderness for some time, why complain now ${ }^{67}$ Second, the grammar of the text seems to point to the fact that Moses had just recently taken this Cushite woman as a wife (cf. Josephus Ant. 2:252-253). ${ }^{68}$ Indeed, the author notes twice not only her ethnicity but also that Moses had 'taken her' (i.e. married her) as a wife. Due to the pervasive presence of Ethiopians/Cushites in Egypt from the Eighteenth Dynasty and

63 It is too facile to follow the perspective of source critics who call this a later insertion. E.g. George B. Gray, Numbers (ICC; Edinburgh: T\&T Clark, 1912): 121-22. 64 See the discussion by Dennis T. Olson, Numbers (Interpretation; Louisville: John Knox, 1996): 70-71.

65 So, J. de Vaux, Les Nombres (Paris: J. Gabalda et $C^{\text {ie }}$ Éditeurs, 1972): 159; and David T. Adamo, 'The African Wife of Moses: An Examination of Numbers 12:1-9', Africa Theological Journal 18.3 (1989): $230-37$ at 232. In the third century AD, the tannaitic tradition Sifre suggests that they are one and the same (see Koltun-Fromm, 'Zipporah's Complaint', 290-91). Also, Hab. 3:7 does put Cushan and Midian together in a parallel couplet, but no definitive conclusion can be drawn from this because Cushan is not necessarily the same as Cush. See discussion by Hays, 'Biblical Perspective', 14-15. While Martin Noth, Numbers, trans. J. D. Martin (OTL; London: SCM, 1968): 94 connects Cushan in Habakkuk 3 and Cush here in Numbers 12 with the region of Midian, he does suggest the woman mentioned here is different from Zipporah. A number of Egyptian and Assyrian texts do note a region in northern Arabia that was known as Kushan: see de Vaux, Les Nombres, 159; Frank Moore Cross, Canaanite Myth and Hebrew Epic (Harvard: Harvard University Press, 1997): 204.

66 See also the detailed discussion by Adamo, 'African Wife', 233-36.

67 So, too, Hays, 'Moses', 60; C. F. Keil, Numbers (COT 1; Peabody, Massachusetts: Hendrickson, 2001): 701; and R. Dennis Cole, Numbers (NAC 3B; Nashville: Broadman \& Holman, 2000): 201. Cole does go on to posit that perhaps Miriam was just using Zipporah's Cushite resemblance as a pretence to address her true grievance, namely, shared authority. See also Renita Weems, Just a Sister Away: A Womanist's Vision of Women's Relationships in the Bible (San Diego, California: LuraMedia, 1988): 71-76. Jacob Milgrom, Numbers (JPS Torah Commentary; Philadelphia: The Jewish Publication Society, 1990): 93 suggests that the Israelites had just recently met Zipporah since she came to meet Moses at Sinai (Exod. 18:2).

68 So, too, Ronald B. Allen, Numbers (EBC; Grand Rapids: Zondervan, 1990): 798; Adamo, 'African Wife', 234; Keil, Numbers, 701; and Gray, Numbers, 121. Josephus links this marriage to Moses' wars in Ethiopia when he was still living in the house of Pharaoh. Baruch Levine, Numbers 1-20 (AB 4A; New York: Doubleday, 1993): 328 proposes that Moses married this Cushite wife while Zipporah was with Jethro after Moses had sent her away. 
onward, ${ }^{69}$ Cushites could easily have been a part of the 'mixed multitude' that came with Israel out of Egypt (Exod. 12:38). ${ }^{70}$ Third, in light of point 2, earlier in Exodus the reader is alerted to the fact that Zipporah was from Midian, hence a Midianite (Exod. 2:15-16). Moreover, Zipporah's father is always identified as a Midianite (Exod. $2: 16 ; 3: 1 ; 18: 2$ ), never as a Cushite. This is the case just two chapters earlier in Numbers 10:29-32. ${ }^{71}$ Conversely, here in Numbers 12:1 the wife of Moses is identified as a Cushite, which is the regular designation for an Ethiopian in the Hebrew text (cf. Gen. 10:6; $2 \mathrm{Kgs}$ 19:9; Isa. 20:3, 5; 37:9; 43:3; 45:14; Ezek. 30:4-5; 38:5; Nah. 3:9). ${ }^{72}$ Not surprisingly, the LXX renders hakkushit (הְְָּשׁׁית) as 'Ethiopian'

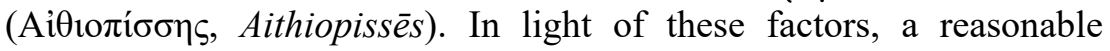
conclusion is that Moses had recently remarried because of the earlier abandonment of Zipporah.

Of course, it could be argued that Zipporah may have died, thus allowing Moses the freedom to remarry. ${ }^{73}$ While this is indeed possible, it seems unlikely due to the fact that such an event certainly would have been noted in the text; after all, the deaths of Miriam (Num. 20:1), Aaron (Num. 20:28), and that entire generation (Num. 32:13) are noted, so why not the very wife of Moses? Others may suggest that Moses took a second wife. ${ }^{74}$ This, too, seems unlikely if in fact Moses wrote most of the Torah. The book of Genesis alone critiques bigamy on more than one occasion (cf. Gen. 4:19; 16; 21; 28:9; 29-30).

In light of the above discussion, it seems more reasonable to conclude that Zipporah had returned with her father Jethro in Exodus 18 and had left Moses alone once again. With this abandonment, Moses felt the freedom to remarry. ${ }^{75}$ For some reason, Moses had opted to marry a Cushite who was not from the nation of Israel but apparently, like Ruth later (Ruth 1:16), had aligned herself with Israel

\footnotetext{
69 Hays, 'Biblical Perspective', 13-14.

70 So, too, Hays, 'Biblical Perspective', 10-11; and Adamo, 'African Wife', 236.

71 Hays, 'Biblical Perspective', 15. See also Adamo, 'African Wife', 233.

72 Philip J. Budd, Numbers (WBC 5; Waco, Texas: Word, 1984): 136. See also Gordon J. Wenham, Numbers (TOTC; Downers Grove, Illinois: Inter-Varsity, 1981): 110; and Adamo, 'African Wife', 233-36.

73 Allen, Numbers, 797-98; Keil, Numbers, 701.

74 So Hays, 'Biblical Perspective', 12-13; and Hays, 'Moses', 61.

75 So, too, Allen, “"Bloody Bridegroom”, 269.
} 
and their God, YHWH. ${ }^{76}$ Miriam and Aaron could have been protesting his choice of bride - she was a Cushite - or they may have been upset that he took a second wife while Zipporah was still alive. ${ }^{77}$ One cannot be certain in this case, but one thing is clear: YHWH did not approve of their treatment of Moses. And marrying a foreign (God-fearing?) woman certainly was not against the law of God (cf. Deut. 21:10-14; cf. 1 Cor. 7:39) provided she was not from the idolatrous peoples of Canaan. ${ }^{78}$ Due to their mistreatment of Moses, YHWH's anger burned against both Miriam and Aaron as YHWH declared his support of Moses (12:4-9) and, implicitly, Moses' choice to remarry. Because Miriam appears to have been the instigator of the rebellion, ${ }^{79}$ she was struck with leprosy for a period of time (Num. 12:10-15).

From this narrative one can draw out a couple important points. First, if God was so upset with Moses' choice (i.e. nationality) of wife he certainly makes no mention of it here. ${ }^{80}$ Moreover, the fact that Moses had chosen to remarry because of Zipporah's departure also does not come up in the meeting between YHWH, Moses, Aaron, and Miriam. Instead, God chose to focus on his close relationship with Moses and his approval of his service. This leads to the second major issue: how God views Moses and those who refused to accept Moses' choice of wife. God obviously saw nothing wrong with Moses' decision to marry a Cushite or his choice to remarry. ${ }^{81}$ As such, those who chided him for it were dealt with severely.

From a Pauline perspective, Paul appears to be giving instruction to the Corinthians along a similar line of argumentation. If an unbelieving spouse leaves, the believer is not 'bound', but is in fact free to remarry, just like Moses had. If a believer chooses this path, then other believers should be careful not to create an atmosphere of contention for the believer. ${ }^{82}$ In this case, Paul's admonition that the believer is called to

76 Hays, 'Biblical Perspective', 18 n.46.

77 So, Levine, Numbers 1-20, 328.

78 Hays, 'Biblical Perspective', 19-20.

79 The use of the feminine singular verb form wattedabber (v.1 וַתִ 1 ) seems to point to the fact that Miriam is leading the rebellion (cf. Exod. 15:1; Judg. 5:1; Esth. 9:29, 32). See Cole, Numbers, 200; Allen, Numbers, 797; and Milgrom, Numbers, 93.

80 Cross, Canaanite Myth, 204, suggests that Miriam's punishment of white leprous skin was a result of her prejudice against Moses' black wife.

81 Hays, 'Biblical Perspective', 19; Hays, 'Moses', 61.

82 See similar sentiments by Gerald L. Borchert, '1 Corinthians 7:15 and the Church's Historic Misunderstanding of Divorce and Remarriage', Review and Expositor 96.1 (1999): 125-29. 
'peace' (eirēene; 1 Cor. 7:15) may be a double entendre. First, the former marriage of a believer may have lacked eirēne due to religious tensions, something not pleasing to God. And secondly, in the case of abandonment, the choice of the believer to remarry is something between them and God. Such a decision should not engender church strife for all are called to 'peace' (eirēnē; cf. Rom. 12:18; 14:19; 2 Cor. 13:11; Eph. 2:14-16; 4:3; Phil. 2:1-4; Col. 3:15).

\section{Did Paul Use OT Allusions in 1 Corinthians 7:12-15?}

While it is certainly true that some may reject the above historical reconstruction of Moses' marital life and/or its influence on Paul's teaching in 1 Corinthians 7:12-15, people who do so must keep in mind that this scenario is in fact possible. This is especially true in light of how intertextual allusions are often used by NT authors. ${ }^{83}$ Richard B. Hays argues that there are seven factors to keep in mind when proposing an intertextual allusion. These include: (1) availability, (2) volume, (3) recurrence, (4) thematic coherence, (5) historical plausibility, (6) history of interpretation, and (7) satisfaction. ${ }^{84}$ In the case which has been argued above, Paul's possible use of texts from the Torah related to Moses' life certainly meet the qualification of number 1 easily enough. ${ }^{85}$ As for number 2, Paul obviously used the Torah/Law on numerous occasions and was not above appealing to the Torah narratives to prove a point (Gal. 4:22-31; cf. Rom. 9:15; 10:5-10, 19; 1 Cor. 9:9; 10:2-6; 2 Cor. 3:7, 13, 15). Moreover, Hayes notes approximately fifty-five potential 'echoes' and/or direct references to the Torah in Paul's writings, more than any other portion of the Hebrew Bible. ${ }^{86}$ Paul even mentions Moses by name (and his life experiences) more times in his correspondence with the Corinthian church than any other epistle (1 Cor. 9:9; 10:2-6; 2 Cor. 3:7, 13, 15). In this vein, it is also important to keep in mind that when teaching on marriage and divorce Paul (a former Pharisee; Phil. 3:5) would have

\footnotetext{
83 See for example the numerous allusions between John and Ezekiel as demonstrated by Brian Neil Peterson, John's Use of Ezekiel (Minneapolis: Fortress, 2015).

84 Richard B. Hays, Echoes of Scripture in the Letters of Paul (New Haven: Yale University Press, 1989): 29-32.

85 Hays, Echoes, 29-30.

86 Hays, Echoes, 231-32. All the prophets combined have a little over thirty references (see Hays, Echoes, 232).
} 
certainly gone to the Torah for a precedent, just as Jesus had. Paul's appeal to Jesus' perspective in 7:10 only bolsters this position especially in light of the fact that Jesus anchored his teaching on the sanctity of marriage to Genesis 1 and 2.

Next, numbers 3 and 4 certainly fit the parallels between the texts in question. The recurrence of specific Greek terms and themes noted for Moses' marital situation and the circumstances faced by an abandoned believer have thematic coherence. What is more, as pointed out above, Paul liked to draw his teachings from the Torah. If this is the case, then it makes sense that Paul would allude to Moses' marital life, for, as Hays notes, 'this [i.e. recurrence] not only applies to specific words that are cited more than once ... but also to larger portions of Scripture to which Paul repeatedly refers', ${ }^{87}$

Although the history of interpretation (\#6) may not support the assertions for this intertextual allusion, that should not be that surprising in light of the fact that it has only been in more recent years that scholars have begun to draw these types of connections due to what Hays has called a past 'Christian tradition [that] has distorted Paul's voice or missed its undertones' ${ }^{88}$ Furthermore, many Jewish and Christian interpreters have already made the connections as I have visà-vis Moses' marital life in Exodus 4, 18, and Numbers 12. And Jewish interpreters certainly would have no interest in drawing connections between their scriptures and the NT. As for Christian interpreters, it appears that they simply have never asked the question of what could have possibly influenced Paul to draw such a conclusion on abandonment, that is, beyond the new circumstances of believers being married to pagans. Despite these issues it is important to keep in mind that Hays himself concludes that the history of interpretation criterion is the least reliable and that 'this criterion should rarely be used as a negative test to exclude proposed echoes that commend themselves on other grounds' .89

Finally, numbers 5 and 7 certainly are possible in this case. Not only is it historically plausible that Paul would have appealed to the Hebrew Scriptures, having been trained at the feet of Gamaliel (Acts 22:3), but the connections pointed out above make for a satisfying answer to the

$\begin{array}{ll}87 & \text { Hays, Echoes, } 30 . \\ 88 & \text { Hays, Echoes, } 31 . \\ 89 & \text { Hays, Echoes, } 31 .\end{array}$ 
dilemma of where Paul may have found the precedent for his teaching on remarriage for an abandoned believer. Even though Paul's audience may not have picked up on the allusion to Moses' life, this does not preclude one from pointing out the obvious fact that Paul was thoroughly Jewish and thus appealed to his knowledge of the Scripture. ${ }^{90}$

\section{Conclusion}

In light of Paul's instruction on divorce/abandonment, it is indeed possible that he drew upon the precedent set by Moses himself, the great lawgiver, and came to the concession that believers who found themselves abandoned by an unbelieving spouse could remarry. Because the Hebrew text relating the accounts of Moses' marital strife is not as clear as one would like, this may have been the very reason why Paul did not say that God was giving this instruction, but rather that he was making an inspired 'judgement call'. In this case, his instruction was based upon what he understood of the situation that unfolded in Moses' marital life. Paul would have been familiar with the accounts of Moses' life and could have reconstructed Moses' marital situation as follows. Because Zipporah had abandoned Moses due to his Abrahamic faith (Exod. 4:26), Moses released Zipporah from her marital obligations (Exod. 18:2). At this point Moses felt free to marry a second time (Num. 12:1) because he apparently did not feel 'bound' by his previous marriage to Zipporah. Even though his immediate family chided him for his decision, YHWH approved.

Therefore, just as Jesus and the Pharisees had appealed to the Torah for their precedent on marriage and divorce respectively, so, too, Paul may have appealed to the Torah (Exodus and Numbers) to establish his teaching on divorce and remarriage for the abandoned believer. While it is true that some may question this connection as conjectural at best, based upon Paul's use of Torah and Hays' warnings that allusions to the Hebrew Bible many times can only be done with 'shades of certainty'91 it nonetheless does help explain why Paul felt the freedom to go beyond the teaching of Jesus on the issue of divorce and, yes, perhaps even allow remarriage.

90 Hays, Echoes, 30-31.

91 Hays, Echoes, 31. 